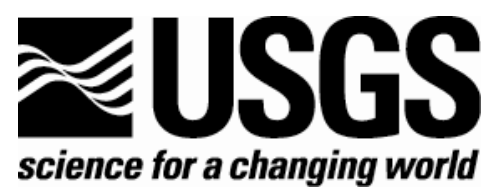

In cooperation with The Alaska Department of Natural Resources

\title{
Water and sediment chemical data and data summary for samples collected in 1999 and 2001 in the Goodpaster River basin, Big Delta B-2 Quadrangle, Alaska
}

Bronwen Wang, Larry Gough, Richard Wanty, Jim Vohden, Jim Crock, and Warren Day

Open-File Report 2006-1131 


\section{U.S. Department of the Interior}

\section{U.S. Geological Survey}

U.S. Geological Survey, Reston, Virginia 2006

Revised and reprinted: 2006

For product and ordering information:

World Wide Web: http://www.usgs.gov/pubprod

Telephone: 1-888-ASK-USGS

For more information on the USGS-the Federal source for science about the Earth, its natural and living resources, natural hazards, and the environment:

World Wide Web: http://www.usgs.gov

Telephone: 1-888-ASK-USGS

Although this report is in the public domain, permission must be secured from the individual copyright owners to reproduce any copyrighted material contained within this report. 


\section{Contents}

Abstract $\quad$ Introduction

\section{List of figures.}

Figure 1. Location of the Big Delta B-2 quadrangle in east-central Alaska, showing its position relative to the Tintina and Denali Faults and cities of Delta Juction and Fairbanks

Figure 2. Geologic map of the Goodpasture B-2 quadrangle based on Day and others (2003). Information regarding the Pogo mine property based on Smith and other (1999) .... 11

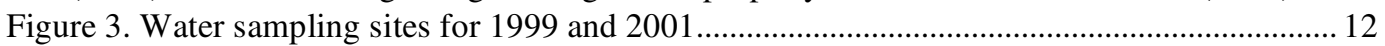

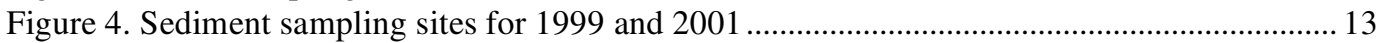

Figure 5. Tri-linear diagram comparing the major ion ratios in water samples collected in 1999 and 2001.

Figure 6. Comparison of A) flow, in cubic feet per second, B) major cations $\mathrm{Ca}$ and $\mathrm{Mg}$, in $\mathrm{mg} / \mathrm{L}, \mathrm{C}$ ) Major anions $\mathrm{CaCO}_{3}$ (from alkalinity) and $\mathrm{SO}_{4}{ }^{2-}$, D) the sum of the $\mathrm{Fe}$ and $\mathrm{Al}$ concentrations and $\mathrm{E}$ ) the sum of the rare earth elements (REE) in water samples collected from sites along California Creek sampled in both 1999 and 2001

Figure 7. Comparison of A) flow, in cubic feet per second, B) major cations $\mathrm{Ca}$ and $\mathrm{Mg}$, in $\mathrm{mg} / \mathrm{L}, \mathrm{C}$ ) Major anions $\mathrm{CaCO}_{3}$ (from alkalinity) and $\mathrm{SO}_{4}{ }^{2-}$, D) the sum of the $\mathrm{Fe}$ and $\mathrm{Al}$ concentrations and $\mathrm{E}$ ) the sum of the rare earth elements (REE) in water samples collected from sites along Occidental Creek sampled in both 1999 and 2001.

Figure 8. Concentration of gold in sediment samples collected from the Big Delta B-2 quadrangle

Figure 9. Concentration of arsenic in sediment samples collected from the Big Delta B-2 quadrangle

List of tables (linked to of2006-1131_tables.xls)

Table 1. Summary statistics for water samples from the Big Delta B-2 quadrangle for 1999 and 2001.

Table 2. Concentrations of major and trace elements in waters from sites along California and Occidental Creeks sampled in both 1999 and 2001.

Table 3. Summary statistics for sediment samples collected in the Big Delta B-2 quadrangle in 1999 and 2001.

Appendixes (linked to of2006-1131_appendixes.xls)

Appendix A. Analytic data for water samples collected in 1999 and 2001 from the Big Delta B-2 quadrangle

Appendix B. Analytic data for sediment samples collected in 1999 and 2001 from Big Delta B-2 quadrangle 


\section{Conversion Factions and Abbreviated units}

$\begin{array}{ccc}\text { Multiply } & \text { by } & \text { To obtain } \\ \text { meter }(\mathrm{m}) & 3.281 & \text { foot } \\ \text { kilometer }(\mathrm{km}) & 0.6214 & \text { mile } \\ \text { square kilometer }(\mathrm{km}) & 0.3861 & \text { square mile }\end{array}$

In this report, temperature is reported in degrees Celsius $\left({ }^{\circ} \mathrm{C}\right)$, which can be converted to degrees Fahrenheit $\left({ }^{\circ} \mathrm{F}\right)$ by the following equation:

$$
\left({ }^{\circ} \mathrm{F}\right)=1.8\left({ }^{\circ} \mathrm{C}\right)+32
$$

\section{Other Abbreviated Units}

$\mathrm{L}$, liter

$\mathrm{mg} / \mathrm{L}$, milligram per liter

$\mu \mathrm{g} / \mathrm{L}$, microgram per liter

$\mathrm{ng} / \mathrm{L}$, nanogram per liter

$\mu \mathrm{m}$, micrometer

$\mu \mathrm{g} / \mathrm{g}$, microgram per gram

ng/g, nanogram per gram

$\mathrm{mg} / \mathrm{kg}$, milligram per kilogram

$\mu \mathrm{S}$, microsiemens 


\section{Water and sediment chemical data and data summary for samples collected in 1999 and 2001 in the Upper Goodpaster River basin, Big Delta B-2 Quadrangle, Alaska}

Bronwen Wang, Larry Gough, Richard Wanty, Jim Vohden, Warren Day, and Jim Crock

\section{Abstract}

We report the chemical analysis for water and sediment collected from the Big Delta B-2 quadrangle. These data are part of a study located in the Big Delta B-2 quadrangle that focused on the integration of geology and bedrock geochemistry on with the biogeochemistry of water, sediments, soil, and vegetation. The discovery of the Pogo lode gold deposit in the northwest corner of the quadrangle was the impetus for this study. The study objectives were to create a geologic map, evaluate the bedrock geochemical influence on the geochemical signature of the surficial environment, and define landscape-level predevelopment geochemical baselines. Important to baseline development is an evaluation of what, if any, geochemical difference exist between the mineralized and non-mineralized areas within a watershed or between mineralized and non-mineralized watersheds. The analytic results for the bedrock, soils, and vegetation are reported elsewhere (Gough and others, 2006). Presented here, with minimal interpretation, is the analytic data for the water and sediment samples collected in the summers of 1999 and 2001 , and a summary statistics of these analyses.

\section{Introduction}

\section{Site characteristics and area geology}

The study site is located in the subarctic boreal forest of east-central Alaska $48 \mathrm{~km}$ northeast of Delta Junction (fig. 1). This region has a continental climate characterized by cold winters and warm summers, low to moderate annual precipitation, and steep, heavily vegetated mountain drainages. Soils in the area were classified as primarily as Cyepts (Inceptisols) and Orthels (Gelisols) (Gough and others, 2006). Discontinuous permafrost is found throughout the region and was typically observed at 15 to $50 \mathrm{~cm}$ below the surface at the soil sample sites (Gough, 2006).

The geology of the area is described in detail in Day and others (2003)) and presented here as figure 2. The crystalline rocks of the Yukon-Tanana Upland underlie the study area (fig.2). Paleozoic gneisses are the predominant lithologies in most the study area, though the Goodpasture batholith is extensive in the north to northeastern section. Gold mineralization, for example that of the Pogo property, is locally spatially and temporally 
associated with various phases of the Cretaceous plutonic rocks (Smith and others, 1999; Day and others, 2003). Two areas of mineralization have been known on the Pogo property: the Liese Zone, which lies between Pogo and Liese Creeks in the northwest section of the property, and a region along the ridge to the south between West and Tam Creeks (Smith and others, 1999). The Liese Zone consists of two large quartz sulfide bodies hosted primarily in gneiss and occasionally in the intrusive rock (Smith and others, 1999). Hydrothermal alteration assemblages in mineralized regions can exert a strong control on water chemistry (Bove, 1996). The Liese zone has been loosely divided into six hydrothermal alteration types: 1) biotite, 2) quartz-silcification, 3) sericite \pm quartz $\pm \mathrm{K}$ feldspar, 4) sericite + ferroan dolomite + chlorite \pm quartz, 5) chlorite, and 6) quartz + calcite \pm green mica. The Liese zone mineralization consists of pyrite, pyrrhotite, loellingite, arsenopyrite, chalcopyrite, bismuthinite, maldonite, native bismuth, native gold, and various $\mathrm{Ag}-\mathrm{Pb}-\mathrm{Bi} \pm \mathrm{S}$ minerals. Sulfide content of the Liese Zone averages about 3 percent, but ranges from trace up to 25 percent (Smith and others, 1999). Mineralization has also been noted associated with the intrusive rock bands of Shawnee Peak on the eastern edge of the study area (Day, 2003).

\section{Methods}

Water and sediment sites were selected based on the regional geology and represent mineralized and nonmineralized areas (figs. 3 and 4). In 1999, 45 sites were sampled for water chemistry, including a downstream sequence of sites along Liese, Occidental, Elwood, Mandate, Sonora, and Shawnee Creeks. In 2001, 28 sites were sampled, including a downstream sequence of sites along Oriental Creek. Nine of the sites sampled in 2001 were also sampled in 1999. Sampling sites were selected on the basis of changes in lithology, appearance of cross cutting structures, and/or changes in the specific conductance of the water.

Water samples were collected as depth- and width-integrated composite sample. Waters were filtered through a $0.45 \mu \mathrm{m}$ syringe-end filter fitted to a $60 \mathrm{ml}$ syringe. Samples for major cation $(\mathrm{Ca}, \mathrm{Mg}, \mathrm{K}, \mathrm{Na})$ and trace element analysis were preserved with ultra-high-purity $\mathrm{HNO}_{3}$; samples for alkalinity and major anion $\left(\mathrm{SO}_{4}, \mathrm{Cl}, \mathrm{F}\right.$, $\mathrm{NO}_{3}$ ) were filtered but not acidified. Sediment samples were collected from several depositional zones combined to form a composite sample. Discharge was measured in cross-section using a pygmy meter except at springs (map number 46 to 48 , and 58,59 ) were discharge was determined using bucket measurements.

All samples were shipped to the Denver USGS Laboratories for analysis. Prior to analysis, sediment samples were dried, sieved to minus- 80 mesh, and ground (Peacock and others, 2002). The ground sediment samples were digested using a four acid digestion; digests were analyzed by inductively coupled plasma - mass spectrometry (ICP-MS) using the methods of Crock and others (1983), Briggs and Meier (2002), Lamothe and others (2002). Hg, S, and Au were analyzed in separate splits of the sediment samples. Sediment samples for Hg analysis were digested with a nitric acid/sodium dichromate and the concentration was determined by cold-vapor atomic absorption spectrometry (CV-AAS) (Brown and others, 2002). Au and total S in sediments were determined by HGA-AAS and combustion, IR respectively (O'Leary and others, 1996; and Curry, 1996).

For waters the major cations $(\mathrm{Ca}, \mathrm{Mg}, \mathrm{K}, \mathrm{Na})$ concentrations were determined by inductively coupled plasma-atomic emission spectrometry (ICP-AES) (Briggs, 2002), trace element concentrations were determined by inductively coupled plasma- mass spectrometry (ICP-MS), and major anions $\left(\mathrm{F}, \mathrm{Cl}, \mathrm{NO}_{3}, \mathrm{SO}_{4}\right)$ by ion chromatography (IC) (Lamothe 2002; Theodorakos and others, 2002). Alkalinity was determined using a preset endpoint ( $\mathrm{pH} 4.5$ ) autotritration system (Theodorakos, 2002). Hg in water was analyzed by CV-AAS (Brown and others, 2002).

Laboratory procedures require instrument calibration with appropriate calibration standard for elements to be reported and analysis of standard reference materials for those elements with appropriate standard reference material. In general the instrumentation calibration and quality control procedures for the laboratory are: 1) Daily hardware and software checks to insure the instrument and its components are working properly 2) Calibration of the instrument using appropriate standards. The calibration standards used contains all the elements that are reported from the analysis. 3) Standard reference materials are run where appropriate. For waters samples the standard reference materials are aqueous reference materials from the U.S. Geological Survey Water Resource Division. Information regarding these reference materials is at http://bqs.usgs.gov/SRS/. 4) Samples are run with every tenth sample being a calibration check solution (i.e. a calibration standard run as a sample). After every 20 samples the 
machine is recalibrated and standard reference materials are run. 5) Each run concludes with a standard reference materials (Lamothe, personal communication).

All analytical data produced for this report are stored in the USGS National Geochemical Database. Within the database values below the reported lower limit of detection (LLD) may be present. In this data summary these data were re-censored to the current LLD for the element (table 1).

\section{Data Summary}

Waters in the Big Delta B-2 quadrangle ranged from $\mathrm{CaCO}_{3}$ type waters to mixed $\mathrm{Ca} / \mathrm{Mg}-\mathrm{CO}_{3} / \mathrm{SO}_{4}$ waters (fig. 5). Trace elements $\mathrm{Ag}, \mathrm{Be}, \mathrm{Bi}, \mathrm{Cr}, \mathrm{Ga}, \mathrm{Ge}, \mathrm{Mo}, \mathrm{Re}, \mathrm{Se}$, and $\mathrm{Tl}$ were not detected in any water sample. Summary statistics of the remaining elements in water are given in Table 1 and the analytic data is given in appendix A. If the number of qualified values exceeded $25 \%$ percent of the total number of samples, summary statistics were not calculated for that element. For elements with qualified values, summary statistics were calculated using the Kaplan-Meier method for censored data as detailed in Helsel (2005).

In 1999, duplicate samples were taken on California Creek, Sonora Creek, and an unnamed tributary to Sonora Creek. No difference in the major cation $(\mathrm{Ca}, \mathrm{Mg}, \mathrm{Na}, \mathrm{K})$ concentrations was found between the duplicate samples. Differences in the major anions ranged from $0-1 \%$ for $\mathrm{CO}_{3}^{-2}, 2.9-4.5 \%$ for $\mathrm{F}^{-}, 0-10.5 \%$ for $\mathrm{Cl}^{-}$, and 0 $2.1 \%$ for $\mathrm{SO}_{4}{ }^{2-}$. Trace elements were at or near the method detection limit in all duplicate samples. In 2001, duplicate samples were taken along California Creek and an unnamed tributary to the Goodpaster River. No difference in $\mathrm{Mg}^{2+}, \mathrm{K}^{+}$and $\mathrm{CO}_{3}^{-2}$ concentrations was found in these duplicates; differences in other major ions ranged from $2.2-2.4 \%$ for $\mathrm{Ca}^{2+}, 0-1.6 \%$ for $\mathrm{Na}^{+}, 0-7.1 \%$ for $\mathrm{F}^{-}, 0-3.8 \%$ for $\mathrm{Cl}^{-}$, and $0-3.8 \%$ for $\mathrm{SO}_{4}{ }^{2-}$. Generally trace elements were at or near the method detection limit in these samples and good agreement was found between duplicate samples for elements with detectable concentrations. Concentrations of all elements were at or below detection in the field blank (appendix A).

Data for all nine sites sampled in both 1999 and 2001 are given in table 2. Interannual variability in the aqueous concentrations of elements is often related to variations in water flow which was significantly higher in 2001 than in 1999 (fig. 6 and 7). Ca, Mg, alkalinity, and $\mathrm{SO}_{4}{ }^{2-}$ concentrations were all lower in 2001 than 1999 (fig. 6 and 7). Differences in flow and elemental concentrations were found at most sites that were sampled in both 1999 and 2001. All duplicated sites except for upper Occidental Creek (site 15, fig. 2) had higher flows in 2001 than in 1999 (figs. 6 and 7, table 2). At the sites where the flow was higher, $\mathrm{Ca}, \mathrm{Mg}, \mathrm{Na}, \mathrm{K}, \mathrm{SO}_{4}^{2-}, \mathrm{CO}_{3}^{-2}$ and $\mathrm{Sr}$ concentrations were lower in 2001 than 1999. In contrast, $\mathrm{Fe}$ and $\mathrm{Al}$ concentrations and elements associated with colloids (for example, the rare earth elements) had higher concentrations in 2001 than in 1999. The differences between major ions and $\mathrm{Fe}$ and $\mathrm{Al}$, and the colloid associated elements, can be explained by dilution of the truly dissolved elements while the higher flows served to mobilize, or keep in suspension, very fine colloids (table 2, figs. 6 and 7).

Summary statistics for the bed sediment samples are given in table 3 and the analytic data is given in appendix B. Summary statistics were not calculated if the number of qualified values exceeded 25 percent of the samples. For elements with qualified values, summary statistics were calculated using the Kaplan-Meier method for censored data (Helsel, 2005).

Concentrations of $\mathrm{Au}$ and As correlated well and the highest values of both $\mathrm{Au}$ and As were located along Liese, Occidental, Elwood, and Sonora Creeks (figs. 8 and 9). Ni, Cr, Fe, Mn, and Co concentrations also correlated and the highest values of these elements were located along Sonora Creek, which may reflect the presence of ultramafic rock units in the area.

\section{Literature Cited}

Brown, Z.A., O'Leary, R.M., Hageman, P.L., and Crock, J.G., 2002, Mercury in water, geologic, and plant materials by continious flow-atomic adsoption spectrometry, in Taggart, J.E., ed., Analytical methods for chemical analysis of geologic and other material: U.S. Geological Survey Open-File Report 02-223, http://pubs.usgs.gov/of/2002/ofr-02-0223/. 
Briggs, P.H., 2002 The determination of twenty-seven elements in aqueous samples by inductively coupled plasma atomic emmisions spectrometry in Taggart, J.E., ed., Analytical methods for chemical analysis of geologic and other material: U.S. Geological Survey Open-File Report 02-223, http://pubs.usgs.gov/of/2002/ofr-02$\underline{0223 / .}$.

Briggs, P.H., and Meier, A.L., 2002, The determination of fourty-two elements in geological materials by inductively coupled plasma-mass spectrometry: in Taggart, J.E., ed., Analytical methods for chemical analysis of geologic and other material: U.S. Geological Survey Open-File Report 02-223, http://pubs.usgs.gov/of/2002/ofr-02-0223/.

Bove, D.J., Kurtz, J.P., Wright W.G, 2002, Geology, Mineralization, and Hydrothermal Alteration and Relationships to Acidic and Metal-Bearing Surface Waters in the Palmetto Gulch Area, Southwesterb Colorado: U.S. Geological Survey Open-File Report 02-275, http://pubs.usgs.gov/of/2002/ofr-02-0275/

Crock, J.G., Lichte, F.L., and Briggs, P.H., 1983, Determination of elements in National Bureau of Standards geological materials SRM 278 obsidian and SRM 688 basalt by inductively coupled plasma-atomic emission spectroscopy: Geostandards Newsletter, v.7, no.2, p. 335-340.

Curry,K.J. 1996, Total Sulfur by combustion, in Arbogast, B.F, ed., 1996, Analytical methods meanual for the Mineral Resources Surveys Program; U.S. Geological Survey Open-File Report 96-525.

Day, W.C., Aleinikoff, J.N., Roberts, P., Smith, M., Gamble, B.M., Henning, M.W., Gough, L.P., and Morath, L.C., 2003, Geologic map of the Big Delta B-2 Quadrangle, East-Central Alaska: U.S. Geolgoical Survey Geologic Investigations Series I-2788, 1:63,360 scale, map with interpretations.

Gough, L.P., Day. W.C., Crock J.G., Gamble, B.M., Henning, M.W., Ager, C. M., Meirer, A.L., Briggs, P.H., Brown, Z.A., and Adams, M. 2006, Regional Geochemistry Results from the Analyses of Rock, Soil, and Vegetation samples -Big Delta B-2 Quadrangle, Alaska: U.S. Geological Survey Open-File Report 1431. http://pubs.usgs.gov/of/2005/1431/

Lamothe, P.J., Meier, A.L., Wilson, S.A., 2002, The determination of fourty-four elements in aqueous samples by inductively coupled plasma-mass specrtometry: in Taggart, J.E., ed., Analytical methods for chemical analysis of geologic and other material: U.S. Geological Survey Open-File Report 02-223, http://pubs.usgs.gov/of/2002/ofr-02-0223/.

Helsel, D.R., 2005, Nondetects and Data Analysis-Statistics for censored environmental data: Wiley-Interscience, Hoboken, New Jersey, 250 pp.

O' Leary, R.M., Meier, A.L., 1996, Gold by flame or graphite furnace atomic absorpiton spectrometry, in Arbogast, B.F, ed., 1996, Analytical methods meanual for the Mineral Resources Surveys Program; U.S. Geological Survey Open-File Report 96-525.

Peacock, T.R, Taylor, C.D., Theodorakas, P.M., 2002, Stream sediment preparation: in Taggart, J.E., ed., Analytical methods for chemical analysis of geologic and other material: U.S. Geological Survey Open-File Report 02223, http://pubs.usgs.gov/of/2002/ofr-02-0223/.

Theodorakos, P.M., d'Angelo W.M., and Ficklin W.H., 2002, Fluoride, chloride, nitrate, and sulfate in aqueous solution utilizing AutoSuppression chemically suppressed ion chormatography: in Taggart, J.E., ed., Analytical methods for chemical analysis of geologic and other material: U.S. Geological Survey Open-File Report 02-223, http://pubs.usgs.gov/of/2002/ofr-02-0223/. 
Captions

Figure 1. Location of the Big Delta B-2 quadrangle in east-central Alaska. The map show the position of the Big Delta B-2 quadrangle relative to the major faults - Tintina and Denali Faults- and the cities of Delta Junction and Fairbanks.

Figure 2. Geologic ma $\mathrm{p}$ of and Pogo mine property location in the Big Delta B-2 quadrangle. The geologic map is based on the map of Day and others (2003). Information regarding the Pogo mine property based on Smith and others (1999).

Figure 3. Location of the 1999 and 2001 water sampling sites in the Big Delta B-2 quadrangle.

Figure 4. Location of the 1999 and 2001 sediment sampling sites in the Big Delta B-2 quadrangle.

Figure 5. Tri-linear diagram comparing the major ion ratios in water samples collected in 1999 and 2001 from the Big Delta B-2 quadrangle. Waters ranged from $\mathrm{CaCO}_{3}$ type waters to mixed $\mathrm{Ca} / \mathrm{Mg}-\mathrm{CO}_{3} / \mathrm{SO}_{4}$ waters.

Figure 6. Comparison of A) flow, in cubic feet per second, B) major cations $\mathrm{Ca}$ and $\mathrm{Mg}$, in $\mathrm{mg} / \mathrm{L}, \mathrm{C}$ ) Major anions $\mathrm{CaCO}_{3}$ (from alkalinity) and $\mathrm{SO}_{4}{ }^{2-}, \mathrm{D}$ ) the sum of the $\mathrm{Fe}$ and $\mathrm{Al}$ concentrations and $\mathrm{E}$ ) the sum of the rare earth elements (REE) in water samples collected from sites along California Creek sampled in both 1999 and 2001.

Figure 7. Comparison of A) flow, in cubic feet per second, B) major cations $\mathrm{Ca}$ and $\mathrm{Mg}$, in $\mathrm{mg} / \mathrm{L}, \mathrm{C}$ ) Major anions $\mathrm{CaCO}_{3}$ (from alkalinity) and $\mathrm{SO}_{4}{ }^{2-}, \mathrm{D}$ ) the sum of the $\mathrm{Fe}$ and $\mathrm{Al}$ concentrations and $\mathrm{E}$ ) the sum of the rare earth elements (REE) in water samples collected from sites along Occidental Creek sampled in both 1999 and 2001.

Figure 8. Concentration of gold in sediment samples collected from the Big Delta B-2 quadrangle

Figure 9. Concentration of arsenic in sediment samples collected from the Big Delta B-2 quadrangle. 


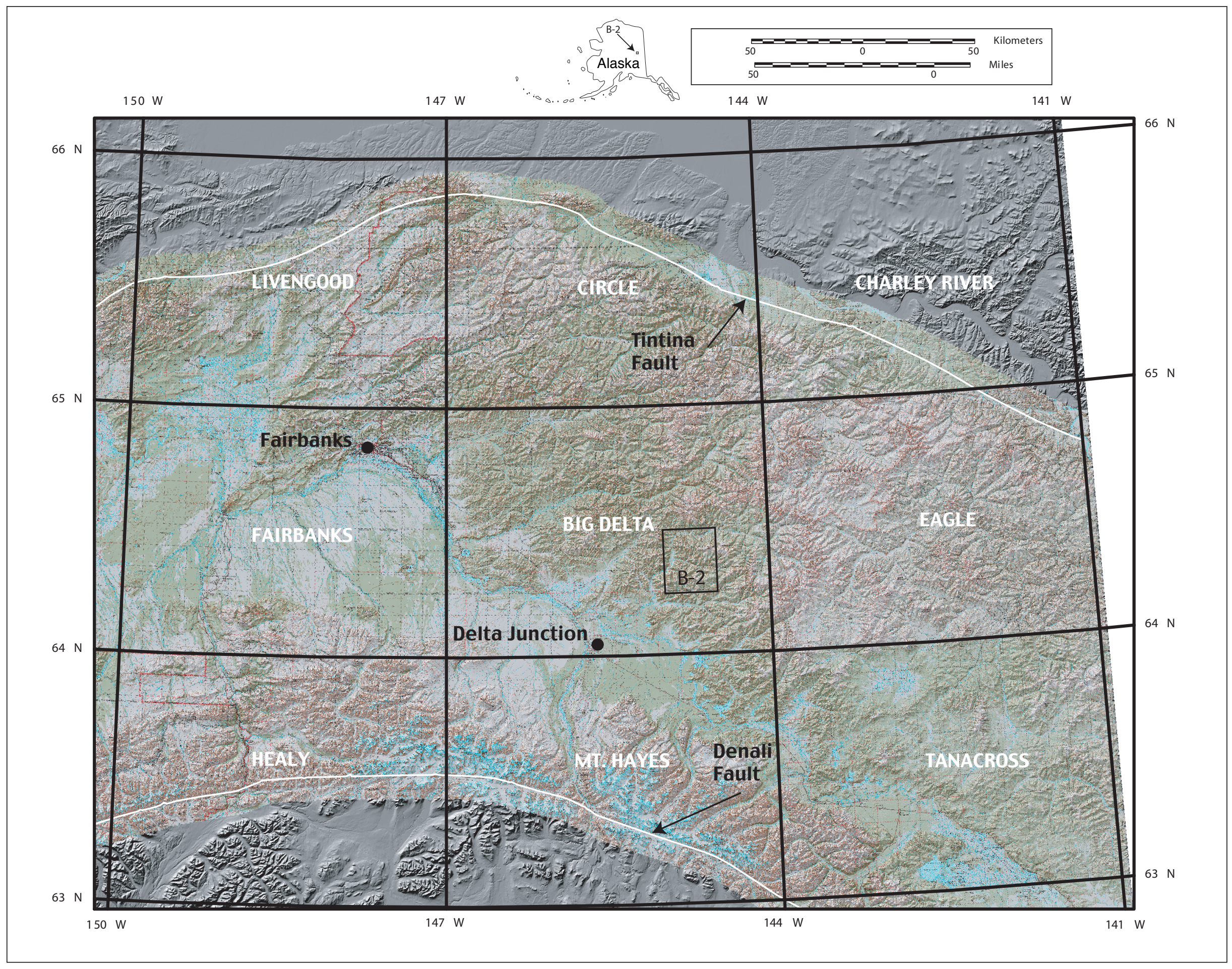




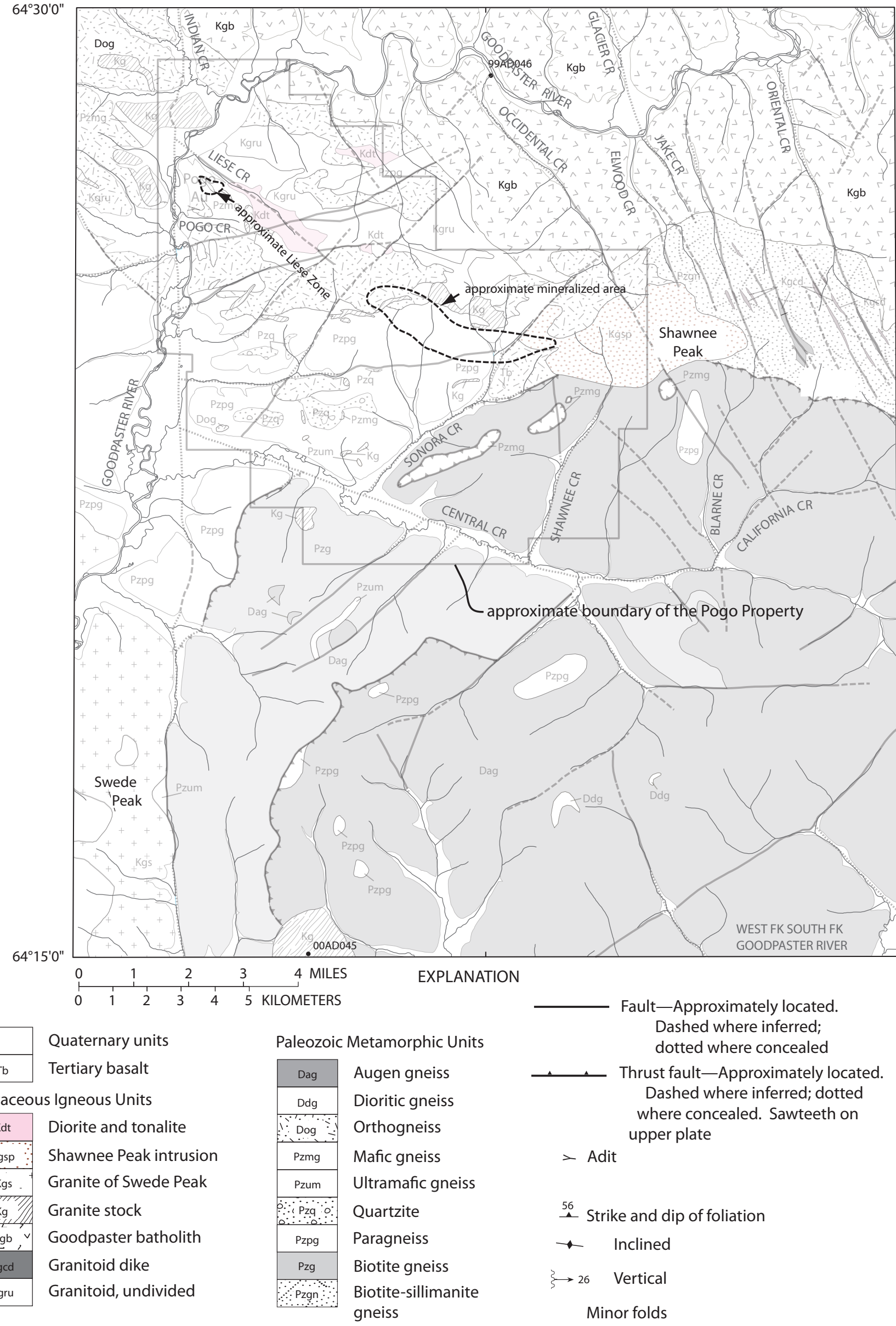

Figure 2. 


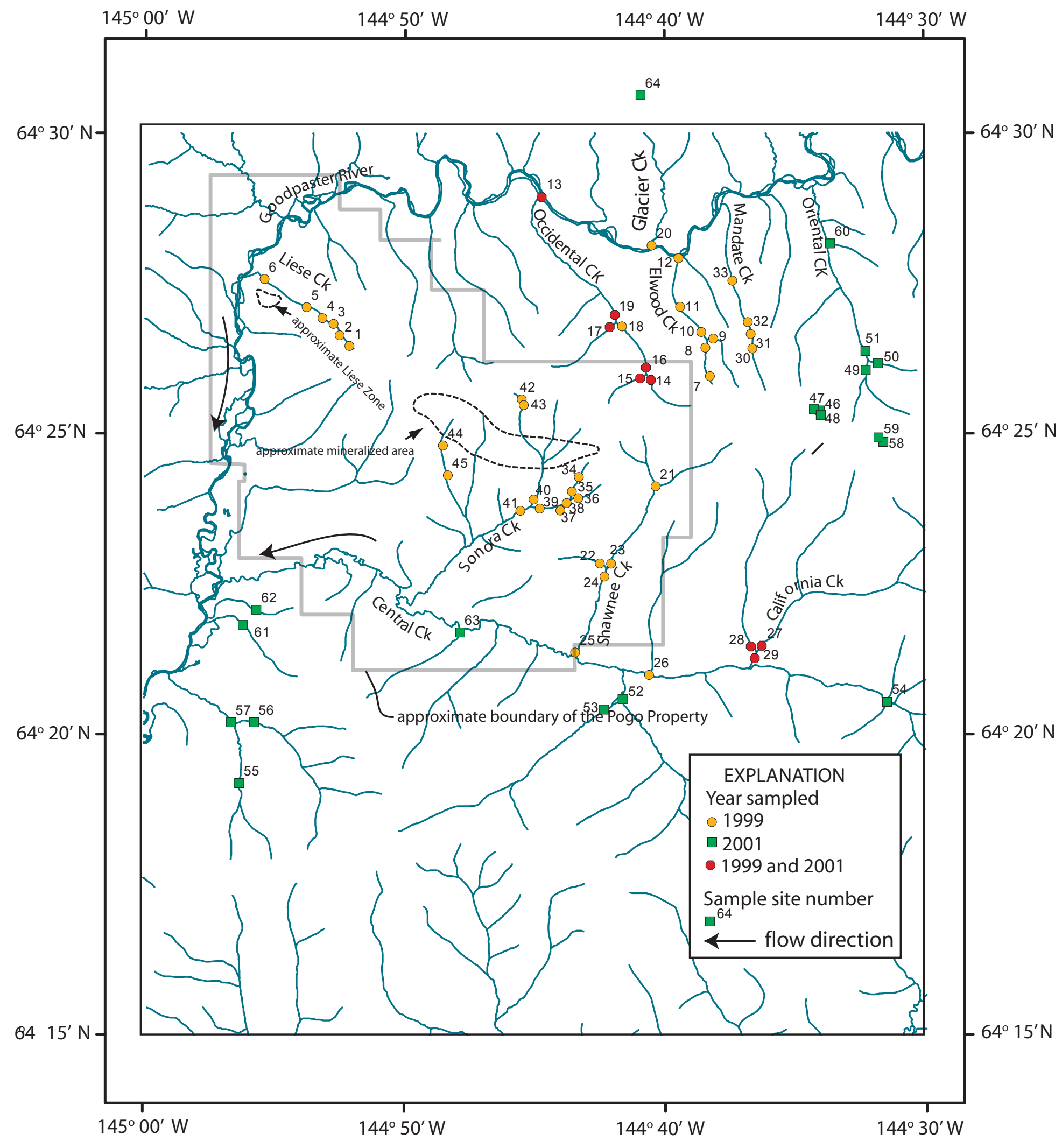

Figure 3. 


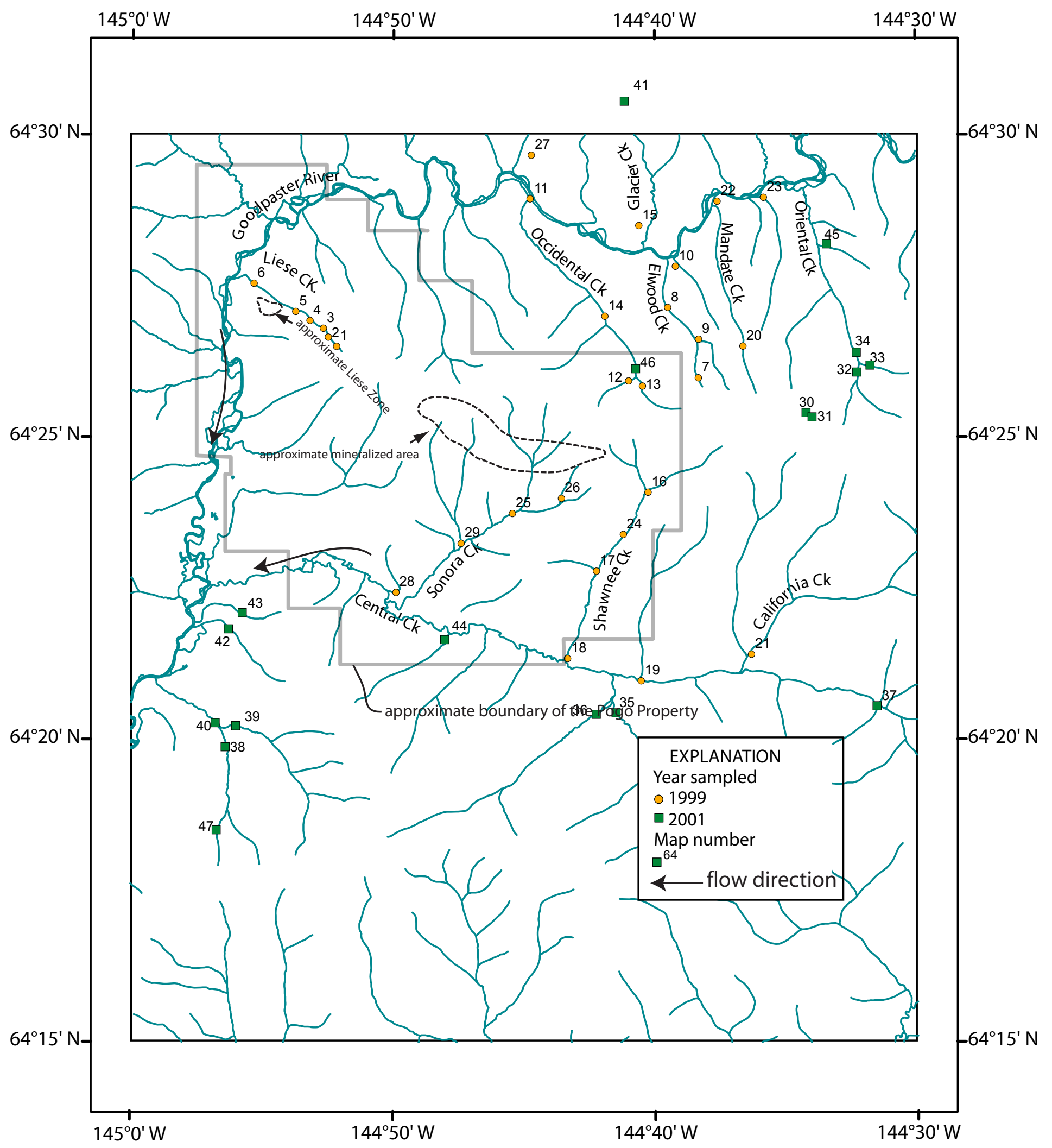

Figure 4. 
Figure 5.

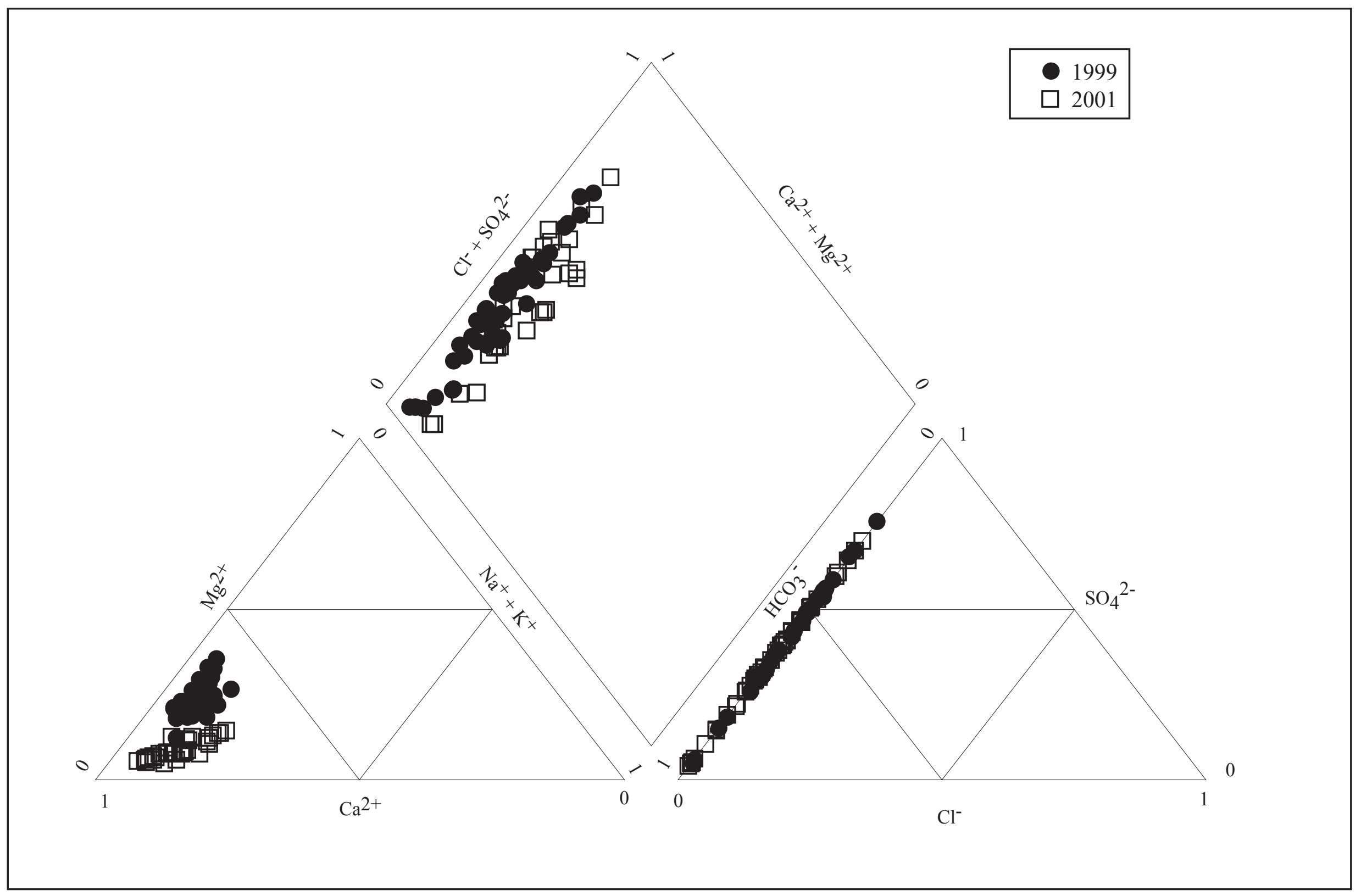



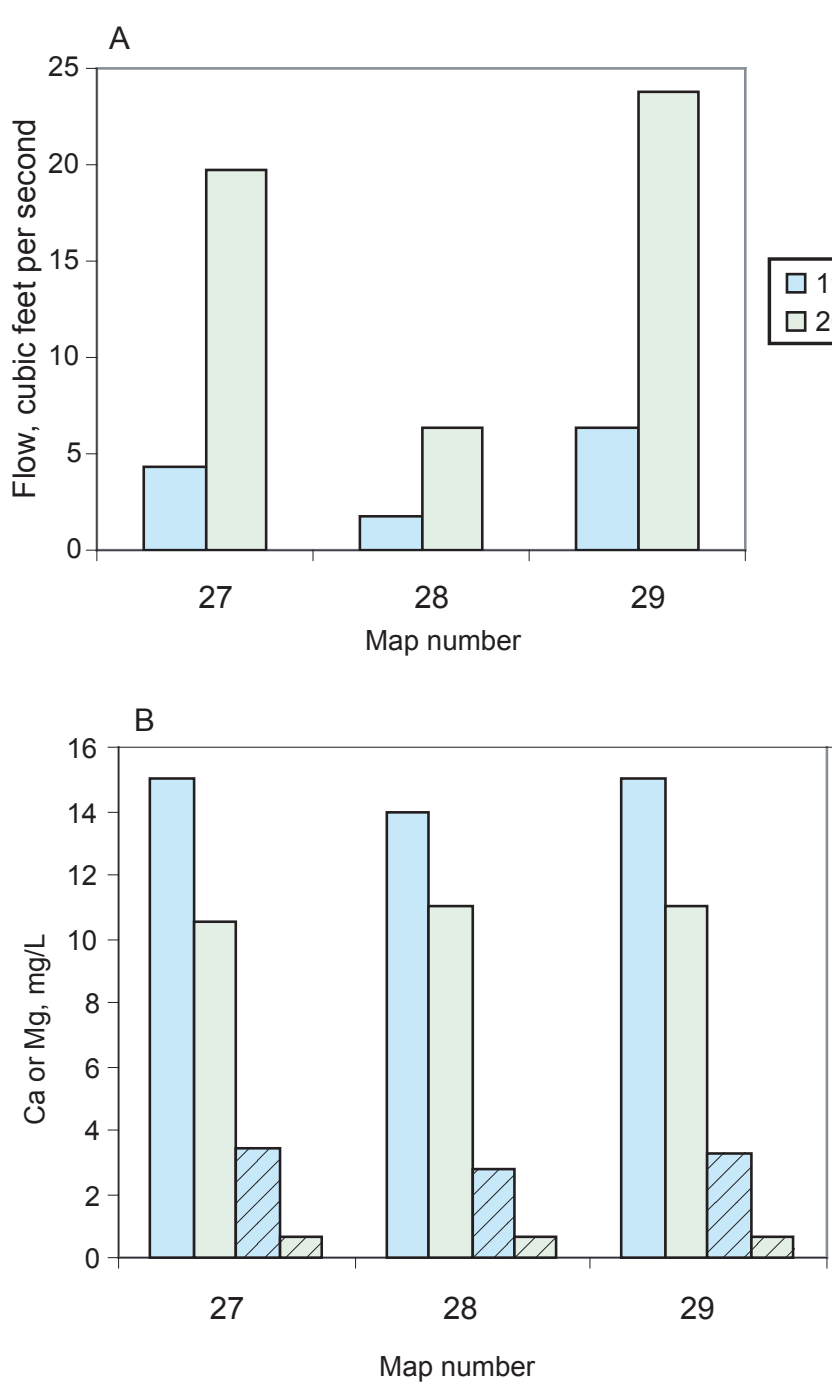

Figure 6.
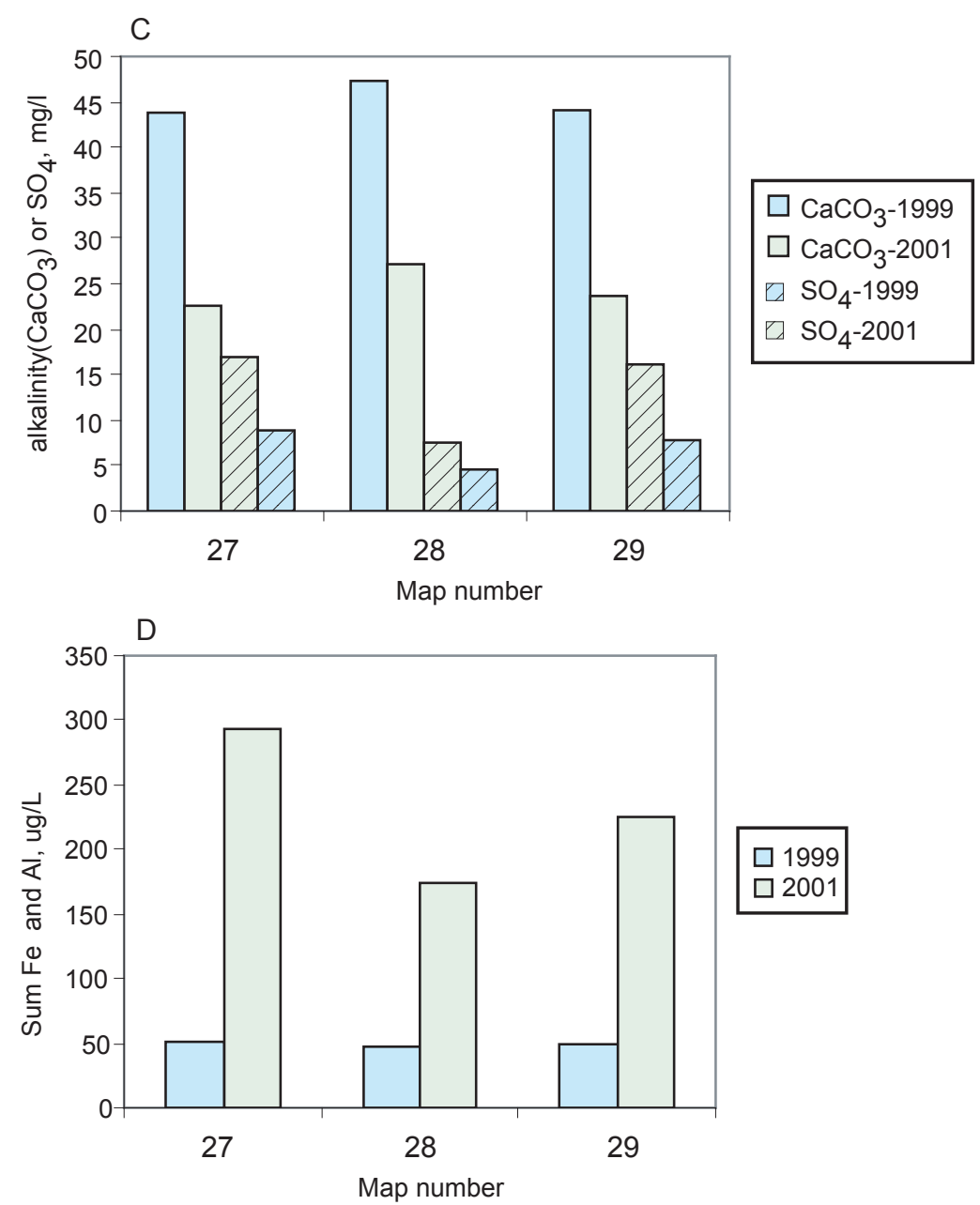

$\square 1999$
$\square 2001$

$\square \mathrm{Ca}-2001$

$\square \mathrm{Mg}-1999$

$\square \mathrm{Mg}-2001$

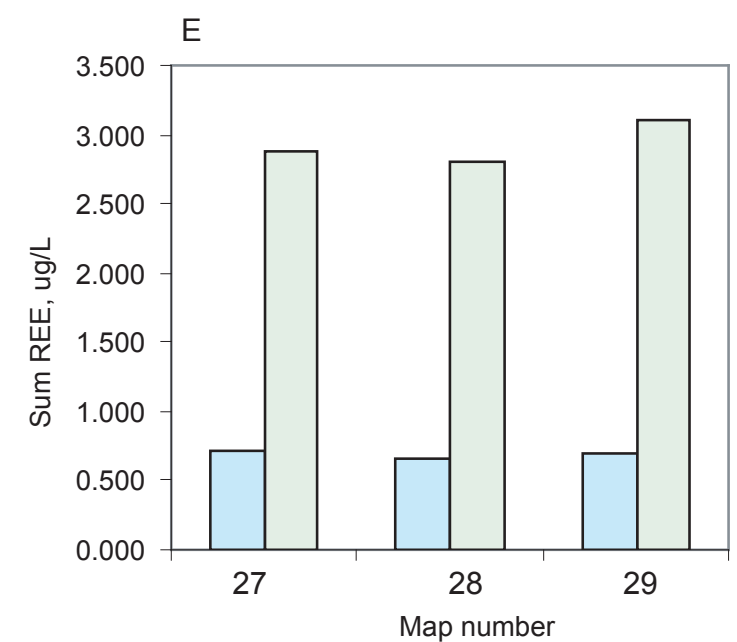



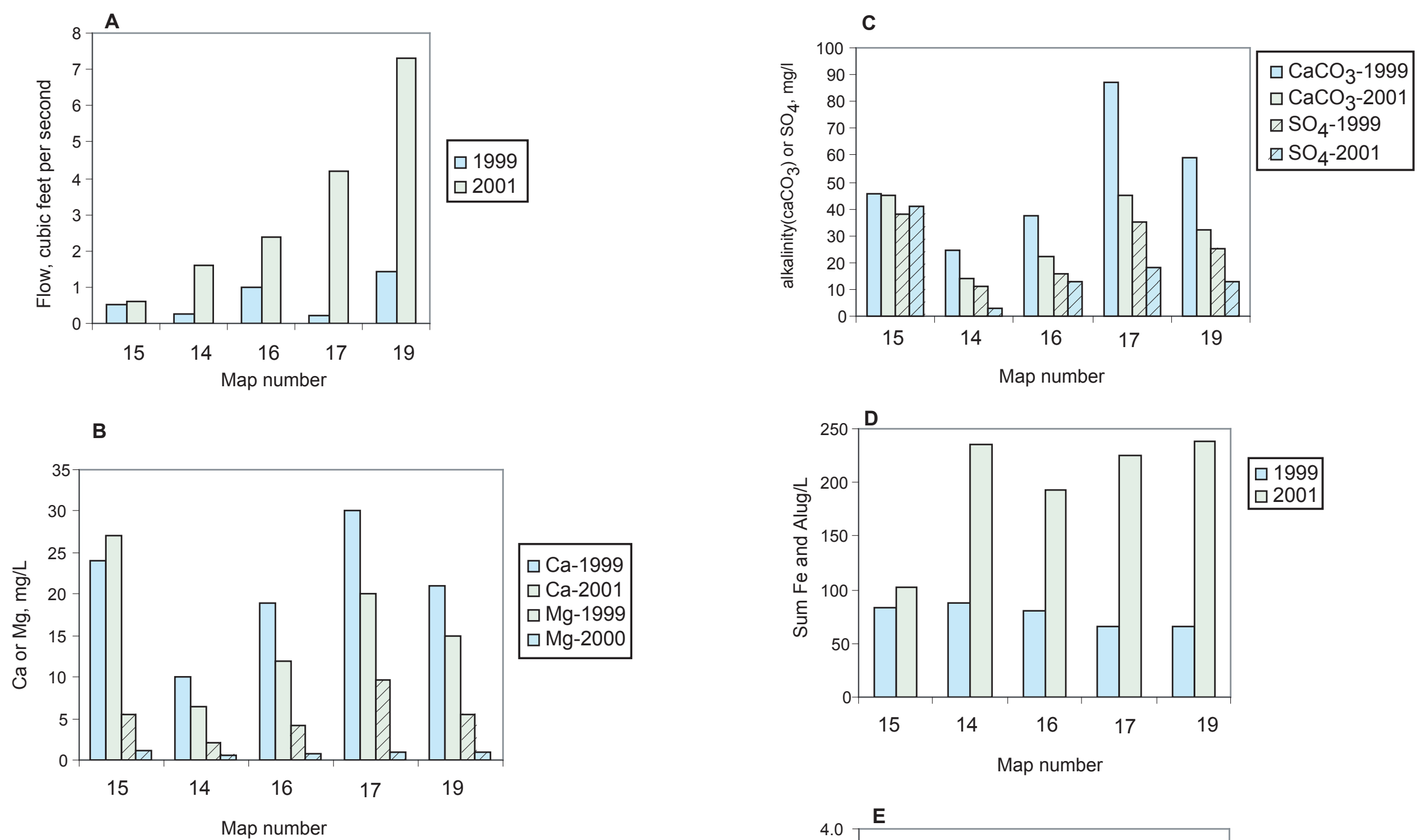

Ca-1999

$\square$ Ca-2001

$\square \mathrm{Mg}-1999$

$\square \mathrm{Mg}-2000$

Figure 7.

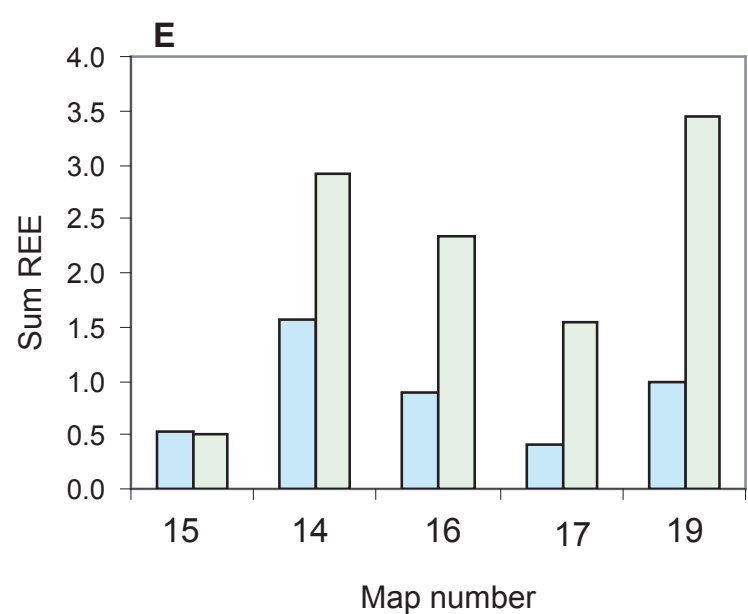

ㅁ1999

$\square 2001$ 


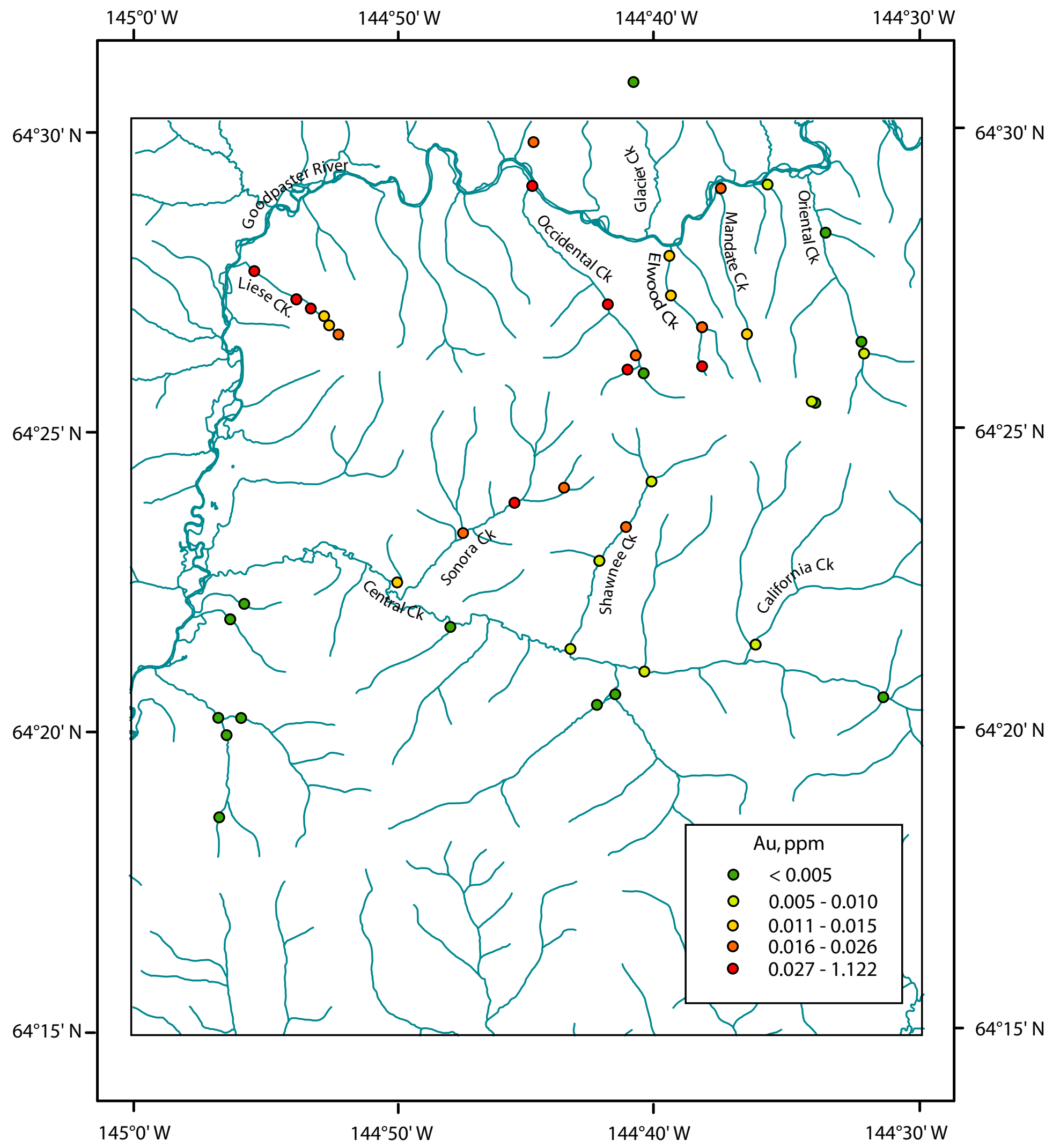

Figure 8 . 


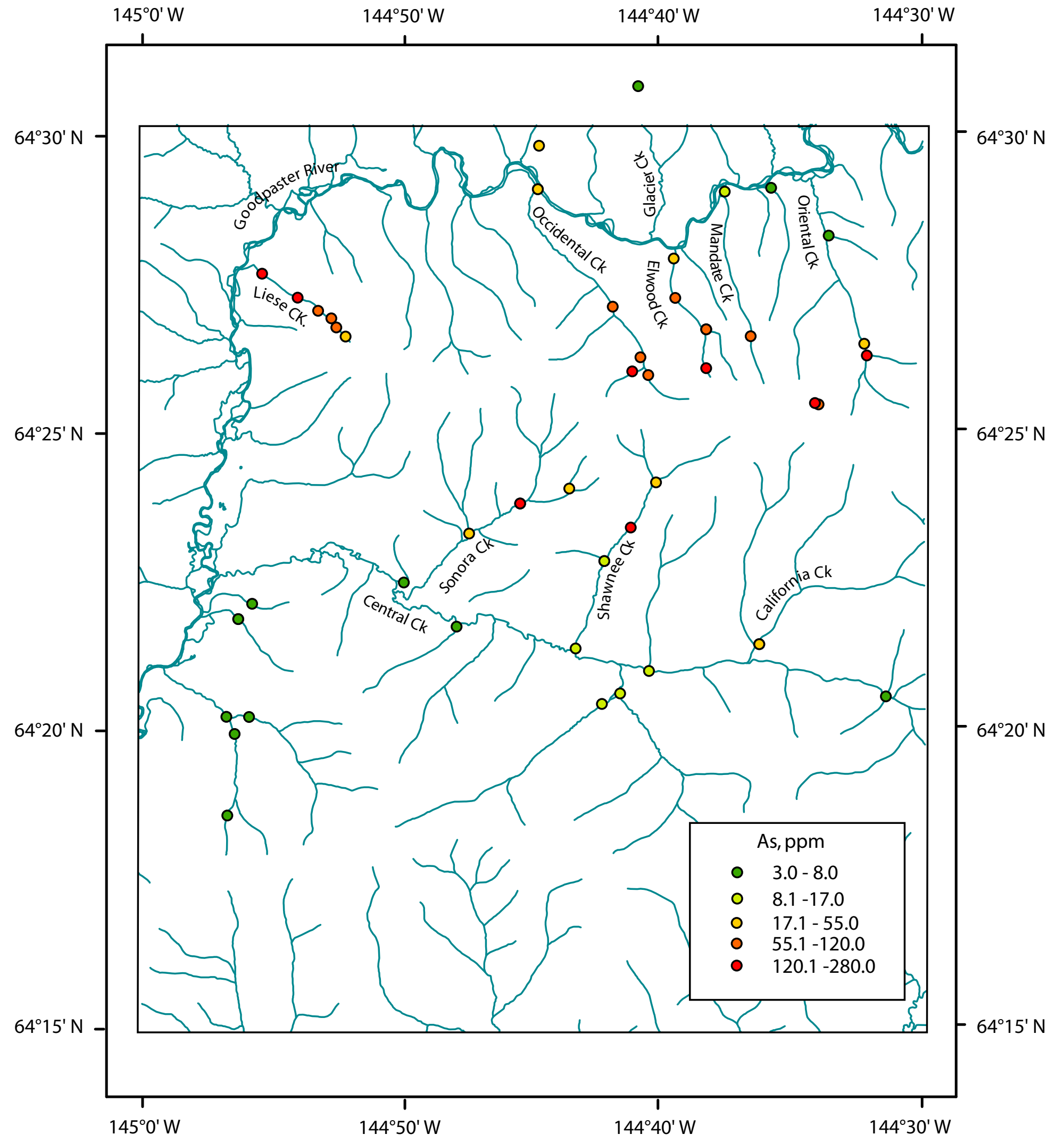

Figure 9. 